\title{
Nakkeskudd med helbredelse
}

\author{
Under kamphandlingene i Ringsaker i april 1940 ble fem norske sivile menn forsøkt henrettet med nakke- \\ skudd av tyske soldater, uten noen prosess eller foranledning. En av disse, en 25 år gammel mann, overlevde \\ imidlertid og kom til behandling på Rikshospitalet tre dager senere. Denne medisinsk sett utrolige hendelsen \\ ble omtalt som kasuistikk i Tidsskriftet i 1945.
}

\section{Bjørn Backe}

bjbac@online.no

Trondheim

I nr. 1/1945 publiserte Tidsskriftet en kasuistikk om en mann som overlevde et forsøk på henrettelse med nakkeskudd, og det uten større skader (1). Historien er sterk og medisinsk sett helt unik. 70-årsmarkeringen av frigjøringen gir anledning til å presentere denne historien på nytt.

Bakgrunnen for hendelsen var krigshandlingene i Ringsaker 20.-21. april 1940, der 15 norske soldater og 22 sivile ble drept (2). De tyske tapstallene er usikre, det er anslått at rundt 40 tyske soldater døde (2). Det er beskrevet at da de døde ble kjørt bort noen dager senere, kom det en rekke på 14 hestesleder med døde tyske soldater (3).

De norske styrkene hadde etablert forsvarsstillinger ved Ring nord for Moelv. Tyskerne omgikk disse stillingene noe lengre øst, og på Lundehøgda ovenfor Ring var det intense kamper (fig 1). Tyskerne fortsatte fremrykningen mot Næroset og Åsmarka, der tyske og engelske styrker for første gang møttes i kamp på bakken under krigen.

De tyske styrkenes brutale fremferd gjorde at lensmannen i Ringsaker foretok rettslig avhør av vitner for å etterforske og dokumentere overgrepene på sivilbefolkningen (4). Avhørene ble foretatt av øyelegen Arne
Mohn som kom til Ringsaker noen dager etter trefningen og meldte seg for lensmannen for å høre om det var noe han kunne bistå med. Mohn ble da umiddelbart konstituert som lensmannsbetjent og satt til å foreta avhør (4). Pasienten som omtales i kasuistikken forklarte seg allerede 24. mai 1940. Både han og flere av de andre som ble avhørt opplyste at noen av de tyske soldatene hadde vært påfallende udisiplinerte. De virket ville, beruset eller påvirket av narkotika. Noen satte dette i forbindelse med at spritlagrene på Strand brenneri ble plyndret og Hitlers fødselsdag ble feiret lørdag 20. april.

\section{Henrettelsene}

Gårdene på Ring var blitt evakuert, men dyra sto igjen i fjøsene. Etter at kamphandlingene stilnet kvelden 21 . april våget noen etter hvert å ta seg frem til gårdene for å melke og fôre kyrene, deriblant den omtalte 25-åringen og hans bror. På gården Svartungstad ble de overrasket av en gruppe tyske soldater. Sammen med tre menn fra nabogården som også var tatt mens de drev med fjøsstellet, måtte de stille seg opp i veikanten. Disse tre var en føderådsmann, hans sønn og svigersønn. Ingen av de fem var militære, bevæpnet eller hadde deltatt $\mathrm{i}$ kamphandlingene på noe vis.

Pasienten fortalte at noen av soldatene hadde ropt «skyt dem, skyt dem», hvorpå «en tykknakket sersjant eller korporal trådte frem med sin pistol og tildelte dem nakke-

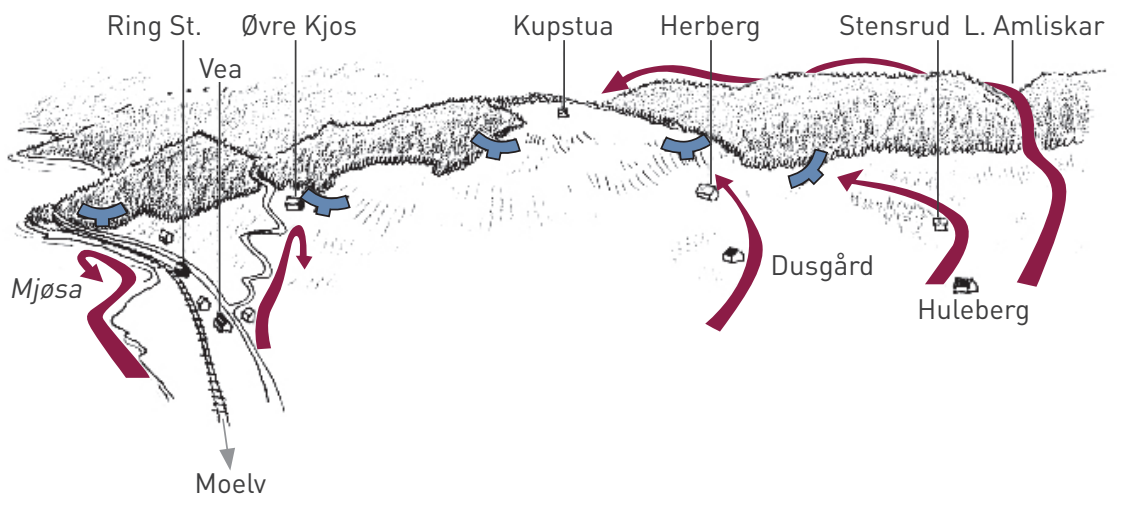

Figur 1 Kartskisse over de norske stillingene (blått) og de tyske troppebevegelsene (rødt) ved kampene på Ring i april 1940 skuddet fra kloss hold, den ene etter den andre» (1). Pasienten var den første som ble skutt, han følte det som et «voldsomt, men ikke synderlig smertefullt slag i nakken, hvorpå han stupte forover mot bakken. Her lå han med full bevissthet og kunne høre hvorledes de fire andre fanger - hvoriblant hans bror - mann etter mann - ble skutt og stupte i bakken» (1). «Han falt da om som om han var død» (3) og «der lå han og ventet på døden som skulle komme - det trakk imidlertid ut - han merket at han kunne bevege både armer og ben og hodet med, og ble snart klar over at han ikke kunne være alvorlig skadet. Av gode grunner besluttet han seg for å ligge ganske stille en god stund inntil tyskerne hadde forlatt stedet - og først nå reiste han seg forsiktig opp» (1).

Forfatteren Odd Eidem som selv opplevde kampene og kjente pasienten, beskriver dette slik: «Selve braket bak ham nedfelte seg i erindringen som et lite dask av to fingertupper. I det samme åpnet han munnen, og ut føk tennene» (3).

Pasienten kom seg etter hvert på beina og gikk for å få hjelp, men ble tatt av en tysk patrulje (1). Disse oppførte seg uklanderlig, i motsetning til den andre gruppen $(2,4)$. Pasienten opplyste at han var blitt skadet av streifskudd fra fly (3). Han passet på å ikke fortelle dem at han kort tid i forveien var forsøkt henrettet. Soldatene førte med seg en gruppe på rundt 20 sivilister, og pasienten måtte følge med. De gikk ca. $15 \mathrm{~km}$ til Bøndernes hus på Brøttum. Der satt de på trebenker over natten, uten å få mat eller drikke. Neste dag ble de løslatt og beordret til å gå hjem. Pasienten klarte å gå hjem - nye $15 \mathrm{~km}$ - og fikk hjelp. Først påfølgende dag kom han seg til Hamar sykehus. Herfra ble han straks sendt med bil til Rikshospitalet, der han ankom tre døgn etter at han var skutt (1).

\section{Kasuistikken i Tidsskriftet}

Kasuistikken om mannen som overlevde nakkeskudd ble skrevet av Herman G. Gade, senere professor i kirurgi i Bergen. Han innleder nøkternt: «Selv om dette kasus i og for seg ikke innebærer så stor interesse hverken i patologisk-anatomisk eller kirur- 


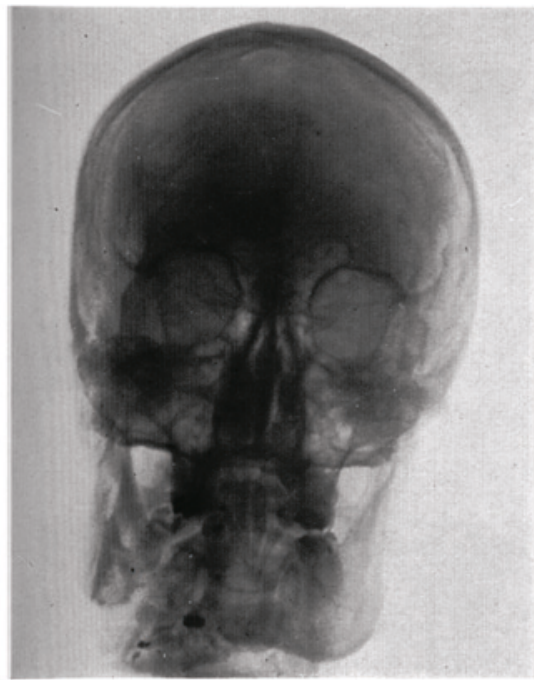

Fig. $t$.

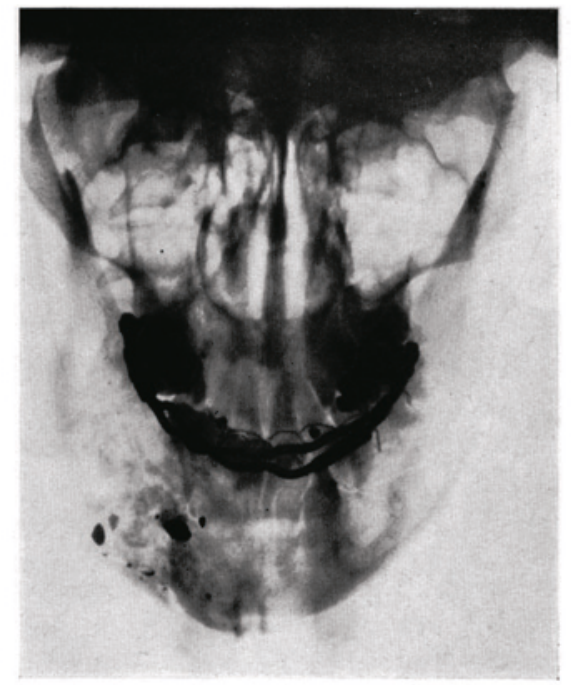

Fig. 3 .

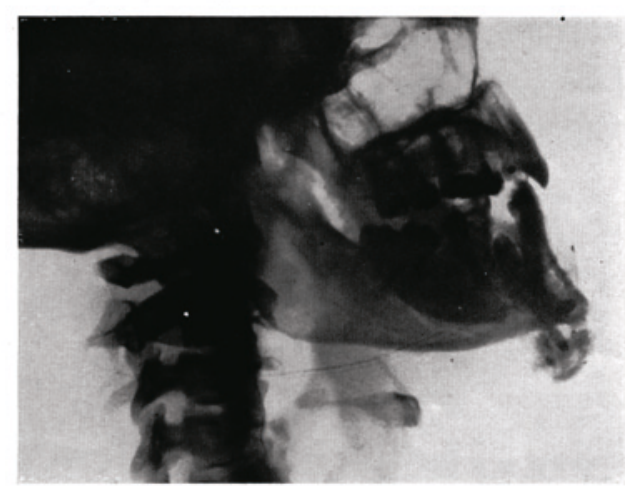

Fig. 2.

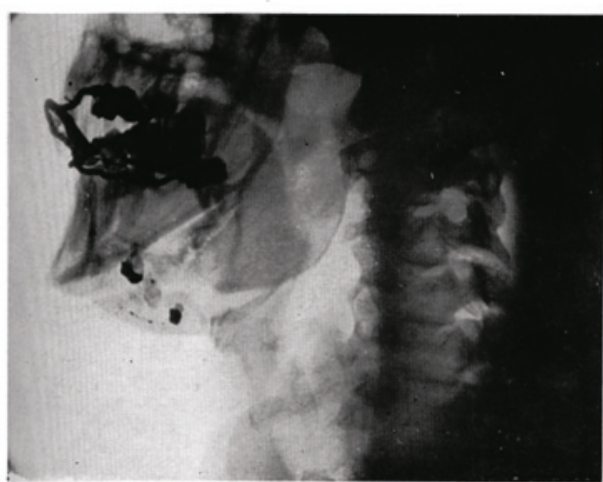

Fig. 4.

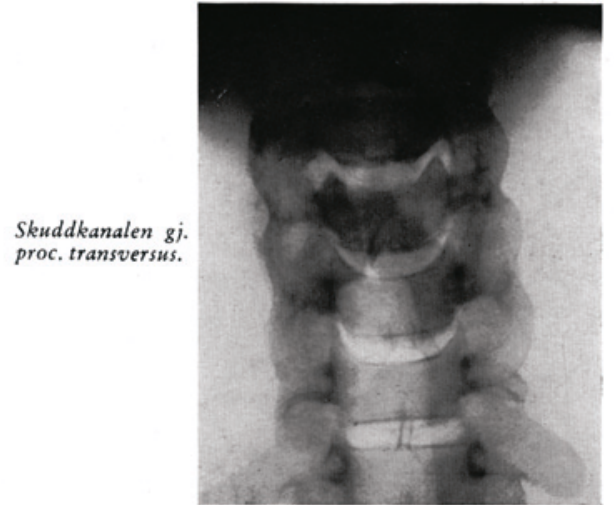

Fig. s.

Figur 2 Faksimile fra kasuistikken i Tidsskriftet, her røntgenbilder tatt av pasienten i 1945, fem år etter at han ble skutt i nakken (1)

gisk henseende, torde pasientens enestående hell alene berettige til en kort omtale» (1).

Pasienten hadde en innskuddsåpning i nakken vel en tommelfingerbredd til venstre for processus spinosus på C3. Utskuddsåpningen var et par fingerbredder til venstre for hakespissen. Åpningen var temmelig stor og opprevet med svulne, betente sårrander. Det var en komminutt faktur av mandibula, og en rekke tenner manglet. Ved inspeksjon av munnhulen var det en moderat submukøs hevelse i venstre sublingvale region. Det var ingen tegn til lesjon av større kar, og ved nevrologisk undersøkelse var det ingen tegn til skade av hjernenerver, ryggmarg eller noen av de spinale nervene.

Det står videre: «I samarbeid med Rikshospitalets daværende tannlæge, dr. Ruud, lyktes det uten særlig vanskeligheter i lokalanestesi å reponere de disloserte fragmenter av kjeven på en ganske tilfredsstillende måte». Man avsto fra å forsøke å fjerne alle spredte fragmenter av tenner og metallstykker «idet man antok at disse bedre ville demarkere og støtes ut spontant». Underkjeven ble fiksert med bøyler på gjenværende tenner. Forløpet var ukomplisert, bortsett fra en submandibulær abscess. «Sekvester, tannstumper og fremmedlegemer støtes ut, og det kom til god konsolidasjon av kjevefrakturen» (1). 
Røntgen av cervikalcolumna ble først gjort i forbindelse med en kontroll i juni 1945 da pasienten ble demonstrert i Det norske medicinske Selskab (fig 2). Bildet «viste at prosjektilet hadde passert gjennom prosessus transversus for C. IV. medialt for a. vertebralis». Gade skrev videre: «Kasus frembyr som nevnt ikke noen synderlig kirurgisk interesse. Han som skjøt traff dårlig, det er hele forklaringen. Følger en imidlertid i tankene prosjektilets bane gjennom nakke, hals og kjeve og erindrer seg de overordentlig tallrike muligheter for alvorlige inntil fatalt forløpende lesjoner som har vært til stede, må en medgi at pasienten - også det feilaktig anbrakte skudd tatt i betraktning -, har vært overordentlig heldig» (1).

I kasuistikken står det videre at ved demonstrasjonen i Det norske medicinske Selskab befant pasienten seg «fullstendig vel og frembød absolutt intet mén etter hendelsen hverken psykisk eller somatisk, bortsett fra de manglende naturlige tenner og en helt lokal hypestesi av underleppen til venstre, svarende til utbredningsgebetet for $\mathrm{n}$. mentalis s. (n. alveolaris inf.)» (1).

\section{I ettertid}

Generaløytnant Pellengahr, som var øverste sjef for de tyske styrkene skal senere ha uttalt at overgrepene mot sivilbefolkningen kastet en skygge over et ellers vellykket felttog (5). Krigshendelsene i Ringsaker ble etterforsket av tyske myndigheter i 1970-årene, og en rekke soldater fra 196. infanteridivisjon ble oppsporet og avhørt. Saken ble lukket i 1977 etter at lederen for etterforskningen slo fast at det var gått for lang tid og at man ikke ville kunne identifisere drapsmennene på grunnlag av vitneforklaringene (5).

Det er ikke vanskelig å slutte seg til konklusjonen i kasuistikken fra 1945 om at pasienten var heldig, selv om han i utgangspunktet var særdeles uheldig som havnet i denne situasjonen og mistet sin bror.

\section{Bjørn Backe (f. 1947)}

er dr.med., spesialist i fødselshjelp og kvinnesykdommer, tidligere overlege og professor emeritus.

Forfatter har fylt ut ICMJE-skjemaet og oppgir ingen interessekonflikter.
Litteratur

1. Gade HG. Nakkeskudd med helbredelse. Tidsskr Nor Lægeforen 1945; 65: 7-9

2. Kristiansen EM. Da tyskera kom. Stange: Stange Historielag, 1990. www.nb.no/nbsok/nb/ 89ad59e261003de5ad18b2c8138790eb?index=1\#0 (6.11.2015)

3. Eidem O. Con amore: erindringshistorier. Oslo: Cappelen, 1983. www.nb.no/nbsok/nb/ 0cf0c88857f4cfb97472068b71c134e1? index=1\#0 (6.11.2015).

4. Henriksen I. Da krigen kom til Moelv. Moelv: Ringsaker historielag, 1965. www.nb.no/nbsok/nb/ Od261 ebecb01fa44052ebec3eabb7739?index=1\#0 (6.11.2015)

5. Svarstad A. Fulle tyskere amok på Ringsaker: Den glemte massakren på Hitlers fødselsdag. Dagbladet 21.4.2015. www.dagbladet.no/2015/04/ 21 /nyheter/pluss/andre_verdenskrig/wwii/hitler/ 38784214/ (7.10.2015).

Mottatt 17.6. 2015, første revisjon innsendt 19.9. 2015, godkjent 7.10. 2015. Redaktør: Kari Tveito. 